\title{
Pengaruh Pemberian ASI Terhadap Kenakalan pada Anak Sekolah Dasar di Yogyakarta
}

\author{
Ferry Andian Sumirat, Mei Neni Sitaresmi, Djauhar Ismail \\ Bagian/SMF Ilmu Kesehatan Anak FK-UGM/RSUP Dr. Sardjito, Yogyakarta
}

\begin{abstract}
Latar belakang. Penelitian menunjukkan keuntungan pemberian ASI pada perkembangan psiko-sosial anak. Selain itu ditemukan korelasi erat antara menyusui dengan pembentukan bonding dan attachment. Kegagalan pembentukan bonding dan attachment akan berpengaruh besar pada perilaku anak pada fase berikutnya. Salah satu bentuk gangguan perilaku anak yang perlu dicermati adalah kenakalan. Kenakalan pada anak berkecenderungan persisten dan berisiko membentuk perilaku kriminal. Untuk itu diperlukan penelitian lebih lanjut untuk mengetahui adakah hubungan antara kenakalan dengan menyusui.

Tujuan. Mengetahui pengaruh lama pemberian ASI sebagai faktor risiko kenakalan.

Metode. Penelitian ini merupakan studi kasus kontrol dengan stratifikasi sampel satu banding satu. Pengumpulan data menggunakan kuesioner dan lembar penilaian perilaku nakal yang diisi oleh orang tua murid sekolah dasar di Yogyakarta. Lembar penilaian ini diadaptasi dari item perilaku delinquent dan agresif CBCL (child behavior checklist). Kasus adalah anak yang dideteksi delinquent dan atau agresif.

Hasil. Validasi alat ukur menghasilkan validitas konstrak item-item antara 0,5649 - 0,8547, koefisien reliabilitas perilaku agresif 0,8549 dan delinquent 0,6281 . Dari 768 responden didapatkan $69(8,9 \%)$ kasus. Anak yang mendapatkan ASI $\leq 6$ bulan memiliki risiko nakal dengan OR (odds ratio) 4,40 (IK=interval kepercayaan 95\%: 1,28-15,90 dan $p=0,006$ ) dibandingkan mendapatkan ASI $\geq 2$ tahun.

Kesimpulan. Pemberian ASI $\leq 6$ bulan merupakan faktor risiko kenakalan pada anak sekolah dasar di Yogyakarta. (Sari Pediatri 2009;10(6):362-6).
\end{abstract}

Kata kunci: lama pemberian ASI, perilaku, delinquent, agresif, kenakalan, merusak

\section{Alamat Korespondensi:}

Dr. Ferry Andian Sumirat, Sp.A. Bagian/SMF Ilmu Kesehatan Anak FK-UGM/RSUP Dr. Sardjito, Jl. Kesehatan no. 1 Yogyakarta. Fakultas kedokteran Universitas Gadjah Mada. Telepon (0274) 587333 psw 301 , Fax.: 0274-583745. E-mail: fa_sumirat@yahoo.com

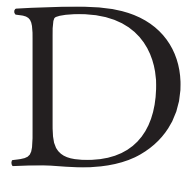

ewasa ini terjadi kecenderungan penurunan pemanfaatan ASI diikuti dengan peningkatan penggunaan susu formula. Departemen Kesehatan (2004) melaporkan peningkatan lebih dari tiga kali pemanfaatan susu formula dari 10,8\% pada tahun 1997 menjadi 32,5\% pada tahun 2002. Berdasarkan analisis SUSENAS 
2001, pertambahan usia bayi menyebabkan penurunan pemberian ASI sebesar 1,3 kali. ${ }^{1}$

Berbagai penelitian menunjukkan ASI terbukti bermanfaat pada semua aspek perkembangan kognitif, 2,3,4,5,6 dan berperan penting dalam perkembangan motorik kasar dan halus serta perkembangan personal-sosial. ${ }^{5}$ Selain itu, pembentukan bonding (kelekatan ibu terhadap anak), dan attachment (kelekatan anak terhadap ibu), ditemukan berkorelasi erat dengan menyusui. ${ }^{7,8}$

Disisi lain, problem perilaku anak terutama kenakalan semakin mengkhawatirkan. Pada tahun 1997 Badan Pusat Statistik (BPS) Indonesia melaporkan bahwa $6,78 \%$ tahanan adalah anak-anak dan 22,02\% remaja. ${ }^{9}$ Di Amerika antara tahun 1980 hingga 1995 terjadi peningkatan kejahatan $94 \%$ yang dilakukan anak dibawah umur 15 tahun dibandingkan $47 \%$ pada remaja ( $>15$ tahun). ${ }^{10}$ Oleh karena itu, kecenderungan peningkatan kenakalan anak merupakan masalah global yang harus diantisipasi sejak dini.

Perkembangan kognitif, motorik, dan personalsosial secara sinergis akan membentuk kematangan perilaku dan kapasitas anak untuk membuat keputusan sosial dan mengontrol tingkah-laku mereka, terutama pada masa prasekolah dan usia pertengahan anak. ${ }^{11,12}$ Hal ini selaras dengan hasil penelitian yang menyebutkan bahwa tidak semua anak yang hidup dalam kemiskinan, atau mempunyai orang tua yang tidak bertanggungjawab akan menjadi nakal, melainkan ada faktor endogen yang ikut berperan. ${ }^{13}$

Bila dikaitkan dengan pengaruh pemberian ASI, kematangan psiko-sosial anak terutama pada aspek kenakalan masih memerlukan pembuktian lebih lanjut. Fergusson dan Woodward ${ }^{14}$ membuktikan manfaat menyusui terhadap kualitas pola asuh orang tua, meskipun demikian tidak ditemukan hubungan antara menyusui dengan perilaku nakal. Sedangkan di sisi lain pola asuh berhubungan erat dengan perkembangan perilaku anak. Kelemahan penelitian Fergusson dan Woodward terletak pada penggunaan remaja sebagai sampel, menimbang sifat kenakalan remaja yang lebih banyak dipengaruhi faktor lingkungan dan seringkali bersifat insidental. Kenakalan pada anak di bawah 13 tahun yang mencapai puncaknya pada rentang umur 8 hingga 10 tahun akan cenderung berlanjut sampai dewasa. ${ }^{15}$ Dengan pertimbangan tersebut, subjek penelitian yang digunakan dalam penelitian kami adalah murid sekolah dasar.

\section{Metode}

Penelitian faktor risiko menggunakan desain studi kasus-kontrol dengan pemadanan karakteristik kasus dan kontrol pada aspek umur, jenis kelamin, kelas, dan sekolah. Studi dilakukan di dua sekolah dasar di wilayah kecamatan Gondokusuman Kotamadya Yogyakarta.

Kasus adalah murid yang teridentifikasi memiliki perilaku agresif dan atau delinquent oleh lembar penilaian yang dibuat berdasarkan adaptasi dari item agresif dan delinquent $\mathrm{CBCL}$ (child behavior checklist) Achenbach. Batas penilaian yang dipakai sesuai dengan batasaan yang dipakai pada CBCL yaitu di atas persentil 98. Sedangkan kriteria eksklusi adalah mereka yang menolak ikut serta dalam penelitian. Kontrol diambil secara random pada murid dengan skor di bawah persentil 95. Selanjutnya variabel bebas yang diteliti adalah lama pemberian ASI yang dihitung dalam bulan. Dengan asumsi odds ratio (OR) 3,5 dan kuasa uji menggunakan power (1- $\beta$ ) 80\% serta tingkat keyakinan $95 \%$ didapatkan jumlah sampel minimum yang dibutuhkan adalah 60 untuk kasus dan 60 untuk kontrol. ${ }^{16}$

Alat ukur kenakalan yang digunakan merupakan hasil adaptasi dari CBCL. Penilaian content validity dan face validity dilakukan oleh ahli psikometri. Uji coba pada minimal 170 responden digunakan untuk mengukur reliabilitas konsistensi internal dan validitas konstrak. Analisis statistik skala psikologi menggunakan koefisien validitas item dengan model Alpha dari Cronbach dan konsistensi antar item. ${ }^{17,18}$ Uji Chi Square digunakan untuk menguji perbedaan karakteristik kelompok kasus dan kontrol dan mendapatkan nilai OR. Sedangkan perbedaan rerata lama pemberian ASI kedua kelompok menggunakan uji Wilcoxon sampel berpasangan. Perangkat lunak Epi Info digunakan dalam penelitian kami.

\section{Hasil}

Dari hasil uji coba alat ukur pada 209 murid SD, diperoleh internal validity item-item perilaku agresif 0,8408-0,8547 dan perilaku delinquent 0,56490,6443 . Adapun koefisien reliabilitas perilaku agresif r 0,8549 dan delinquent 0,6281. Angka tersebut menunjukkan bahwa alat ukur cukup valid dan andal. 
Pada akhir studi didapatkan 69 kasus dan 69 kontrol dari 768 responden dengan tingkat prevalensi kenakalan pada anak SD mencapai 8,9\%. Antara kelompok kasus dan kontrol tidak ditemukan perbedaan karakteristik dalam hal jumlah anggota keluarga, sedangkan karakteristik lain yaitu berasal dari keluarga miskin, ayah pengangguran, orang tua tunggal dan usia ibu saat melahirkan $<18$ tahun tidak dapat dibandingkan karena frekuensi yang diperoleh kecil (Tabel 1).

Lama pemberian ASI baik pada kelompok kasus maupun kontrol paling banyak terjadi untuk pemberian lebih dari 18 bulan. Namun demikian, terdapat perbedaan rerata lama pemberian ASI yang signifikan $(p=0,002)$ antara kedua kelompok tersebut. Dengan menggunakan lama pemberian ASI $>2$ tahun sebagai referen, maka pemberian ASI $<6$ bulan terbukti meningkatkan kemungkinan menjadi nakal 4,4 kali, sedangkan untuk lama pemberian ASI antara 6-12 bulan dan 13-23 bulan tidak meningkatkan kemungkinan menjadi nakal (secara statistik tidak signifikan dengan $p>0,05$ dan IK melewati angka 1) (Tabel 2).

\section{Diskusi}

Prevalensi kenakalan pada murid SD yang didapatkan dalam studi kami, 8,9\%, hampir sama dengan di Amerika pada tahun 1996-1997 (10\%) pada murid SD hingga SMA yang pernah terlibat kriminalitas. ${ }^{19}$ Di Indonesia masih sangat sedikit studi yang membahas kenakalan anak. Selain itu, perbedaan definisi operasional maupun alat ukur yang digunakan merupakan kendala untuk membandingkan prevalensi kenakalan anak dari beberapa negara atau institusi yang berbeda. Sebagian besar laporan tindakan kriminal/ kenakalan oleh sekolah atau institusi penegak hukum lebih mengarah kepada kenakalan yang bersifat overt (jelas) yang dapat mengganggu ketenteraman masyarakat, sedangkan CBCL yang dikembangkan psikolog mengarah pada konsep kenakalan yang lebih luas (overt dan covert) yang ditujukan terutama bagi kepentingan individu tersebut sehingga orang tua dapat mengantisipasi penyimpangan perilaku nakal anak. ${ }^{20,21}$

Hasil studi juga menunjukkan anak yang mendapatkan ASI $\leq 6$ bulan beresiko 4,4 kali lebih

Tabel 1. Karakteristik kelompok kasus dan kontrol

\begin{tabular}{lccc}
\hline Karakteristik & $\begin{array}{c}\text { Murid nakal } \\
(\mathrm{n})\end{array}$ & $\begin{array}{c}\text { Murid tidak nakal } \\
(\mathrm{n})\end{array}$ & $\begin{array}{c}\text { Nilai } \\
p\end{array}$ \\
\hline Jumlah murid & 69 & 69 & \\
Jumlah anggota keluarga (orang) & & & \\
$\quad \leq 5$ & 38 & 43 & \\
$->5$ & 31 & 26 & 0,387 \\
Dari keluarga miskin & 0 & 0 & \\
Ayah pengangguran & 2 & 1 & \\
Orang tua tunggal & 3 & 2 & \\
Umur ibu saat melahirkan $<18$ th & 1 & 1 & \\
\hline
\end{tabular}

Tabel 2. Lama pemberian ASI pada kelompok kasus dan kontrol

\begin{tabular}{lccccc}
\hline $\begin{array}{l}\text { Lama ASI } \\
\text { (bulan) }\end{array}$ & $\begin{array}{c}\text { Kasus } \\
(\%)\end{array}$ & $\begin{array}{c}\text { Kontrol } \\
(\%)\end{array}$ & $\begin{array}{c}\text { Rasio odds } \\
(\mathrm{OR})\end{array}$ & $\begin{array}{c}\text { Interval kepercayaan } \\
(\mathrm{IK}) 95 \%\end{array}$ & $\begin{array}{c}\text { Nilai } \\
p\end{array}$ \\
\hline$\leq 6$ & $14(20,28)$ & $5(7,24)$ & 4,40 & $1,28-15,90$ & 0,006 \\
$7-12$ & $13(18,84)$ & $8(11,59)$ & 2,77 & $0,77-7,15$ & 0,090 \\
$13-23$ & $14(20,28)$ & $16(23,19)$ & 1,25 & $0,48-3,24$ & 0,612 \\
$\geq 24$ & $28(40,57)$ & $40(57,97)$ & 1 & - & - \\
Jumlah & $69(100)$ & $69(100)$ & & & 0,002 \\
Rata-rata & $16(1-48)$ & $21(3-48)$ & & & \\
\hline
\end{tabular}


besar untuk berperilaku nakal dibanding yang mendapatkan ASI $\geq 2$ tahun. Secara tidak langsung hasil ini mendukung rekomendasi WHO untuk memberikan ASI minimal selama 6 bulan, meskipun dalam penelitian ini tidak dibedakan menurut ASI ekslusif atau tidak. Masa 6 bulan pertama merupakan masa kritis pembentukan bonding terutama pada hari-hari pertama kelahiran. ${ }^{22}$ Namun demikian, mekanisme bagaimana pengaruh ASI terhadap kenakalan perlu diteliti lebih lanjut, apakah dari segi biologis ASI atau dari segi kematangan mental dan emosional ibu.

Kendala utama memahami pengaruh ASI pada perkembangan psikososial anak terletak pada sulitnya mengontrol faktor perancu yang berupa kondisi yang melatarbelakangi ibu memutuskan untuk menyusui. ${ }^{23}$ Keputusan menyusui merefleksikan maternal attitude (termasuk self confidence) dan kemampuan ibu memahami situasi. ${ }^{22,23}$ Peran ASI (terutama pada 6 bulan pertama) pada perkembangan psikososial anak bisa jadi lebih mengarah pada aspek pembentukan attachment, bonding, dan perkembangan kognitif anak dibandingkan dengan nilai biologis $\mathrm{ASI}^{7}$ itu sendiri. Perubahan hormonal pada ibu yang menyusui berpengaruh pada penurunan ambang nyeri, ambang stres, euforia, rasa mengantuk dan peningkatan rasa cinta pada bayi, sehingga interaksi ibu dengan anak terbangun lebih baik. ${ }^{7,24,25,26}$

Hasil studi pada 152 ibu menunjukkan bahwa mereka yang memberikan ASI eksklusif dan melakukan inisiasi menyusui memiliki sensitive parenting behaviour (NCAST) lebih baik dengan koefisien korelasi 0,26 $(p=0,008)$ dan $0,39(p=0,000) .{ }^{27}$ Studi intervensional di Swedia terhadap 540 sampel melaporkan adanya peningkatan maternal relationship terhadap bayinya setelah mendapat dukungan ante-natal dan prenatal yang terprogram..$^{28}$ Selain itu ditemukan pula bahwa inisiasi menyusui terkait erat dengan bonding dan keberhasilan meyusui. ${ }^{7,8}$

Meskipun demikian apakah parenting behaviour atau fungsi biologi ASI atau gabungan keduanya yang mempengaruhi perkembangan anak masih merupakan pertanyaan besar yang belum jelas terjawab. Kecenderungan pemahaman manfaat menyusui lebih terpusat pada bayi dibanding ibu memerlukan studi lebih lanjut. Dari studi yang ada tidak ditemukan perbedaan antara keluaran pembentukan kelekatan (attachment) bayi pada ibu yang memberikan ASI dibandingkan yang tidak; ASI sampai 3 bulan $(p=0,742)$; memberikan ASI eksklusif 3 bulan $(p=0,128)$; dan inisiasi menyusui $(p=0,876) .{ }^{27}$ Manfaat ASI diduga lebih terletak pada pembentukan bonding yang merupakan modal utama pembentukan pola asih-asah-asuh yang baik. Sebagaimana diketahui perkembangan dan pertumbuhan anak sangat memerlukan asih-asah-asuh. ${ }^{29}$

\section{Kesimpulan}

Riwayat lama pemberian ASI $\leq 6$ bulan merupakan faktor risiko perilaku nakal anak SD di Yogyakarta. Perilaku nakal anak merupakan salah satu masalah besar yang dikhawatirkan orang tua dan masyarakat. Oleh karena itu diharapkan ada perubahan pola promosi ASI yang lebih menekankan manfaat ASI pada pembentukan perilaku anak agar lebih mengena. Penelitian berbasis populasi dan dengan rancangan studi longitudinal sangat diperlukan sehingga diperoleh hasil studi yang lebih mencerminkan populasi dan mampu memprediksi faktor risiko.

\section{Daftar Pustaka}

1. Purnamawati S. Faktor-faktor yang berhubungan dengan pola pemberian asi pada bayi usia empat bulan (analisis data susenas 2001). Didapat dari: http://digilib.litbang. depkes.go.id (diunduh: 18 oktober 2008).

2. Angelsen NK, Vik K, Jacobsen G. Breast feeding and cognitive development at age 1 and 5 years. Arch Dis Child 2001;85:183-8.

3. Horwood LJ, Darlow BA, Mogridge N. Breastmilk feeding and cognitive ability at 7-8 years, Arch. Dis. Child Fetal Neonatal 2001;84:23-7.

4. Horwood LJ, Fergusson DM. Breastfeeding and later cognitive and academic outcomes. Pediatrics 1998;101:20-7.

5. Morley R, Fewtrell MS, Abbott RA. Neurodevelopment in children born small of gestational age: a randomized trial of nutrient-enriched versus standard formula and coparison with a reference breastfed group. Pediatrics 2004;113:515-21.

6. Lucas A, Morley R, Cole TJ. Randomized trial of early diet in preterm babies and later intelligent quotient. Brit Med J 1998;317:1481-7.

7. Kennell JH, Klaus MH. Bonding: recent observations that alter perinatal care. Pediatr Rev 1998;19:4-12. 
8. Lamb ME. Early contact and maternal-infant bonding: one decade later. Pediatrics 1982;70:763-8.

9. Badan Pusat Statistik (bps) Indonesia, Social welfare statistic. Didapat dari: Http://www. bps.go.id/sector (diunduh: 12 Juni 2004).

10. Butts JA, Snyder HN. The youngest delinquents: offenders under age 15. OJJDP(September), USA: Department of Justice; 1997.

11. Elkind D, Weiner IB. Development of the child. New York: John Wiley and Sons; 1978. h. 150-3, 271-2.

12. Simonof E, Elander J, Holmshaw J. Predictors of antisocial personality. Brit J Psyc 2004;184:118-27.

13. Monks FJ, Knoers AMP, Haditono SR. Psikologi perkembangan: pengantar dalam berbagai bagiannya. Yogyakarta: Gadjah Mada University Press; 2004. h. 382-5.

14. Fergusson DM, Woodward LJ. Breastfeeding and psychosocial adjustment. Pediatr and Perinatal Epid 1999; 13:144-57.

15. Loeber R, Farrington DP, Petechuk D. Child delinquency: early intervention and prevention. Child delinquency bulletin series (May), USA: Department of Justice; 2003.

16. Schlesseman JJ. Case-control studies: design conduct analysis. Oxford: University Press; 1982. h. 160-2.

17. Azwar S, Penyusunan skala psikologi, Yogyakarta: Pustaka Pelajar; 2004.

18. Singarimbun M, Effendi S, penyunting. Metode penelitian survei. Jakarta: LP3ES; 1995. h. 140-3.

19. Heaviside S, Rowand C, Williams C. Violence and discipline problem in U.S. public school: 1996-97, Fast Response Survey System (FRSS), Statistical analysis report, national centre of education statistics. USA: Department of Education; 1998.
20. Bank L, Duncan T, Patterson GR. Parent and teacher rating in the assessment and prediction of antisocial and delinquent behaviors. J Person 1993;61:693-707.

21. Kelley BT, Loeber R, Keenan K. Developmental pathways in boys disruptive dan delinquent behavior. OJJDP (Desember) USA: Department of Justice; 1997.

22. Musen $\mathrm{PH}$, penyunting. Handbook of child psychology. Edisi 4, Volume 1 dan 4, USA: John Wiley \& Sons; 1983.

23. Woodward LJ, Liberty KA. Breastfeeding and child psychosocial development. Dalam: Tremblay RE, Barr RG, Peters RDeV, penyunting. Encyclopedia on Early Childhood Development. Montreal, Quebec: Centre of Excellence for Early Childhood Development; 2005. h. $1-7$.

24. Gribble KD. Mental health, attachment and breastfeeding: implications for adopted children and their mothers. International breastfeeding journal 2006;1:1-15.

25. Heinrich M, Meinlschmidt G, Neumann I. Effect of suckling on hyphotalamic-pituatary-adrenal axis response to psychosocial stress in postpartum lactating women. J. Clin Endocrinol. Metab 2001;86:4798-804.

26. Altemus M, Deuster PA, Galliven E. Suppression of hyphothalamic-pituitary-adrenal axis response to stress in lactating women. J Clin Endocrinol Metab 1995;80:2954-9.

27. Britton JR, Britton HL, Growbwaldt V. Breastfeeding, sensitivity, and attachment. Pediatrics 2006;118:e143643.

28. Ekström A, Nissen E. A mother's feelings for her infant are strengthened by excellent breastfeeding counseling and continuity of care. Pediatrics 2006;118:e309-14.

29. Soetjiningsih. Tumbuh Kembang Anak, Jakarta: EGC; 1995. 